\title{
JULIO CEZAR MENDES
}

Geologia e Petrologia da Intrusão do Rio Novo do Sul - ES

\section{Orientador: Cristina Maria Wiedemann}

\section{Resumo :}

O presente trabalho é apoiado no mapeamento geológico em escala $1: 25.000$, de uma área com aproximadamente $80 \mathrm{~km}^{2}$, nas imediações da cidade de Rio Novo do Sul, sul do Estado do Espírito Santo, onde ocorrem vários corpos de rochas intrusivas (Complexo Intrusivo de Rio Novo do Sul), cuja composição varia de quartzo-dioritos a granitos (litotipos intermediários: quartzo-monzodioritos, quartzo-monzonitos, tonalitos e granodioritos), encaixadas em ortognaisses de idade Brasiliana e gnaisses bandados migmatizados (sillimanita-granada gnaisses) de idade provavelmente Transamazônica. Esse conjunto está posicionado no Complexo Alegre, que por sua vez faz parte do Cinturão Móvel Ribeira, de idade Brasiliana.

Dados magnetométricos indicam a existência de forte anomalia na região, permitindo inferir a ocorrência de um amplo magmatismo básico em subsuperfície. Esse fato, somado à forma irregular da intrusão, faz com que ela seja interpretada como um conjunto de apófises e "stocks".

Dentre as rochas intrusivas, predominam granodioritos homogêneos e quartzo-dioritos. Os outros tipos afloram em pequenas porções, isoladamente ou em zonas mistas de rochas, podendo também corresponder a variações composicionais localizadas.

A estrutura de fluxo, linear ou planar, pode ser bem desenvolvida, tendendo ao paralelismo com a xistosidade das rochas encaixantes. O grau de deformação não é expressivo, predominando tipos litológicos homogêneos e sem complicações estruturais, excetuando algumas porções quartzo-dioríticas, onde se observa fluxo turbulento, pequenas zonas de cisalhamento dúctil e veios sin-intrusivos falhados.

Os contatos com as rochas encaixantes e aqueles entre as rochas das diferentes porções do complexo raramente estão expostos. Nas zonas mistas de rochas ocorrem tanto contatos bruscos quanto irregulares, assim como estruturas tipo pillow.

Uma grande quantidade de diques graníticos e veios quartzofeldspáticos cortam todos os litotipos, com orientação e formas variadas. Diques de microdiorito de pequena espessura são intrusivos principalmente nos gnaisses, fundindo-os localmente.

A petrografia das rochas do Complexo Intrusivo de Rio Novo do Sul é simples, uma vez que os termos litológicos possuem composições mineralógicas semelhantes e texturalmente são hipidiomórficos granulares ou porfiríticos. O feldspato potássico dominante é a microclina, muitas 
vezes micropertítica. 0 anfibólio possui, provavelmente, composição ferrohastingsítica, não estando presente nos granitos e aparecendo nos granodioritos como acessório. Em várias amostras esse mineral acha-se transformado em biotita, enquanto que somente numa seção delgada, correspondente a quartzo-diorito, verifica-se augita diopsídica com borda de anfibólio. Constata-se reações entre os feldspatos: em alguns casos o plagioclásio corrói microclina e vice-versa, e em outras situações nota-se o intercrescimento entre quartzo e microclina (intercrescimento gráfico) e quartzo e plagioclásio (mirmequita). Os cristais de plagioclásio e as biotitas formam a foliação primária das rochas com fluxo desenvolvido. Nos microdioritos o plagioclásio pode exibir bordas corróidas. Apatita e zircão são os minerais acessórios mais frequentes.

Comparando-se com análises químicas de rochas semelhantes da literatura, o quimismo do Complexo Intrusivo de Rio Novo do Sul revela um magmatismo enriquecido em $\mathrm{Fe}, \mathrm{K}, \mathrm{Ti}$ e $\mathrm{P}$ (principalmente granodioritos e quartzo-dioritos) e levemente depletado em Na. As composições mineralógica e normativa nos mostra tipos litológicos supersaturados em sílica, e de caráter peraluminoso $\left(\mathrm{Al}_{2} \mathrm{O}_{3} / \mathrm{Na}_{2} \mathrm{O}+\mathrm{K}_{2} \mathrm{O}+\mathrm{CaO} * 1,1\right)$.

Quanto a determinação do tipo petrogenético dos granitóides, predominam rochas da série magnetita, e observa-se nos vários diagramas estudados características de magmas tanto tipo I quanto tipo S. Uma tendência cálcio-alcalina/álcali-cálcica para o complexo aqui estudado é observada em diversos diagramas, com rochas geradas provavelmente em ambiente de transição (final do ciclo compressivo/início do ciclo extensivo).

O que parece predominar na formação das rochas do Complexo Intrusivo de Rio Novo do Sul são processos de cristalização fracionada, não se excluindo a participação de mecanismos de fusão parcial e mistura de magmas.

O Complexo Intrusivo de Rio Novo do Sul exibe características que se assemelham com outros complexos intrusivos do sul do Espírito Santo, como por exemplo os maciços de Castelo e Iconha, situados a nortenoroeste e nordeste, respectivamente, da área aqui estudada. 